\title{
Optimalisasi Portofolio Nilai Saham: Studi Komparasi Kinerja Saham Syariah dan Nonsyariah
}

\author{
Ferry Khusnul Mubarok \\ Universitas Islam Negeri Walisongo Semarang \\ email: ferrykhusnulmubarok@walisongo.ac.id
}

\author{
Ahmad Ridho Darmawan \\ Universitas Islam Negeri Walisongo Semarang \\ email: ahmadrdy17@gmail.com
}

\section{Zahirotul Luailiyah}

\author{
Universitas Islam Negeri Sunan Kalijaga Yogyakarta \\ email: kedunglo26@gmail.com
}

\begin{abstract}
The objective of this research is to analyze the comparison of sharia and nonsharia stock performance. The sample is a company listed on the Indonesia Stock Exchange, listing from 2013-2017. The sample consists of nonsharia stock (LQ45) and sharia stock (Jakarta Islamic Index). Sampling method used purposive sampling technique. Data analysis technique used RiskAdjusted Return Measurement and analyzed by using paired sample T-Test. Based on analysis and discussion, there is no significant differences between portfolio performance of LQ45 and JII, either using Sharpe, Treynor, and Jensen alpha Index. Based on annual data, the performance of JII's portfolio is better than LQ45 when macroeconomic is depression, while LQ45 portfolio performance is better when macroeconomic is booming. Thus, JII portfolios are more effective used when the economy is depressed, while LQ45 is more effective when the economy is booming.
\end{abstract}

Keywords: Sharpe Index; Treynor Index; Jensen alpha Index; portfolio performance; sharia and nonsharia shares.

Abstrak: Penelitian ini bertujuan untuk menganalisis perbandingan kinerja saham syariah dan nonsyariah. Sampel dalam penelitian ini adalah perusahaan yang terdaftar di Bursa Efek Indonesia, yang listing dari tahun 2013-2017. Sampel terdiri atas saham nonsyariah (LQ45) dan saham syariah (Jakarta Islamic Index). Metode pengambilan sampel menggunakan teknik purposive sampling. Teknikanalisis data menggunakan Risk-Adjusted Return Measurement dan dianalisis menggunakan uji beda rata-rata dua sampel (paired sampel TTest). Hasil analisis dan pembahasan menunjukkan bahwa kinerja antara portofolio LQ45 dan JII secara keseluruhan tidak memiliki perbedaan signifikan, baik menggunakan pengukuran indeks Sharpe, Treynor, maupun Jensen alpha. Jika dibandingkan berdasarkan tahun, maka kinerja portofolio JII lebih tahan

Economica: Jurnal Ekonomi Islam - Volume 8, Nomor 2 (2017) 
terhadap kondisi makroekonomi yang kurang stabil, sementara kinerja portofolio LQ45 memiliki respon kinerja yang lebih baik terhadap kondisi makroekonomi. Dengan demikian, pemilihan portofolio optimal saham syariah lebih tepat pada saat terjadi pelemahan ekonomi, sedangkan pada masa pemulihan ekonomi kinerja portofilo optimal terdapat pada indeks LQ45.

Kata Kunci: Indeks Sharpe; Indeks Treynor; Indeks Jensen alpha; kinerja portofolio; saham syariah dan nonsyariah.

\section{Pendahuluan}

Investasi pada instrumen keuangan syariah di beberapa negara terutama di Indonesia berkembang cukup pesat. Hal ini disebabkan oleh adanya pengaruh ajaran agama Islam (sharia compliant) yang cukup kuat. Pertumbuhan investasi syariah tersebut juga didorong oleh peningkatan demand investor muslim, terutama karena meningkatnya nilai modal populasi umat Muslim di dunia. Oleh karena itu, investor muslim membutuhkan produk-produk keuangan yang tidak bertentangan dengan ajaran Islam (Derigs and Marzban 2009). Berdasarkan beberapa kajian riset sebelumnya, instrumen keuangan yang mendasarkan pada nilai-nilai Islam memiliki kelebihan dibandingkan dengan instrumen keuangan konvensional. Kelebihan ini salah satunya dapat dinilai dari kinerja portofolio indeks pasar tersebut. Penelitian yang dilakukan oleh Touiti (Touiti 2017) menunjukkan bahwa kinerja indeks syariah lebih baik dibanding dengan indeks konvensional terutama pada saat krisis. Hal yang sama juga diungkapkan oleh Mehmood et al. (Mehmood, Akhter, and Shahbaz 2016) yang menyatakan bahwa kinerja saham syariah dapat dijadikan instrumen hedging, karena memiliki kinerja yang lebih baik terhadap krisis keuangan. Selain itu, kelebihan indeks syariah juga dapat dilihat dari rendahnya risiko, yang menunjukkan bahwa kinerja tersebut juga dapat dikatakan baik. Sukmana dkk (Sukmana and Kholid 2012) menjelaskan bahwa risiko indeks syariah lebih kecil dibanding indeks konvensional terutama pada saat terjadi krisis. 
Investasi pada instrumen keuangan syariah di beberapa negara terutama di Indonesia berkembang cukup pesat. Hal ini disebabkan oleh adanya pengaruh ajaran agama Islam (sharia compliant) yang cukup kuat. Pertumbuhan investasi syariah tersebut juga didorong oleh peningkatan demand investor muslim, terutama karena meningkatnya nilai modal populasi umat Muslim di dunia. Oleh karena itu, investor muslim membutuhkan produk-produk keuangan yang tidak bertentangan dengan ajaran Islam (Derigs and Marzban 2009). Berdasarkan beberapa kajian riset sebelumnya, instrumen keuangan yang mendasarkan pada nilai-nilai Islam memiliki kelebihan dibandingkan dengan instrumen keuangan konvensional. Kelebihan ini salah satunya dapat dinilai dari kinerja portofolio indeks pasar tersebut. Penelitian yang dilakukan oleh Touiti (Touiti 2017) menunjukkan bahwa kinerja indeks syariah lebih baik dibanding dengan indeks konvensional terutama pada saat krisis. Hal yang sama juga diungkapkan oleh Mehmood et al. (Mehmood, Akhter, and Shahbaz 2016) yang menyatakan bahwa kinerja saham syariah dapat dijadikan instrumen hedging, karena memiliki kinerja yang lebih baik terhadap krisis keuangan. Selain itu, kelebihan indeks syariah juga dapat dilihat dari rendahnya risiko, yang menunjukkan bahwa kinerja tersebut juga dapat dikatakan baik. Sukmana dkk (Sukmana and Kholid 2012) menjelaskan bahwa risiko indeks syariah lebih kecil dibanding indeks konvensional terutama pada saat terjadi krisis.

Penelitian tentang perbandingan kinerja portolio saham syariah dan konvensional telah banyak dilakukan. Meskipun demikian, masih terdapat perbedaan hasil dari beberapa kajian ilmiah (riset) terdahulu. Berdasarkan studi literatur, secara umum hasil penelitian dapat dibedakan dalam tiga kelompok, yaitu: kelompok yang menyimpulan bahwa tidak terdapat perbedaan kinerja, kelompok yang menyimpulkan bahwa kinerja saham konvensional lebih baik dibanding saham syariah, dan kelompok yang menyimpulkan bahwa kinerja saham syariah lebih baik dibanding saham konvensional. Penelitian yang masuk dalam kategori kelompok pertama 
antara lain, penelitian yang dilakukan oleh Setiawan dkk (C. Setiawan and Oktariza 2013) dan Pranata dkk (Pranata and Nurzanah 2015) yang menyimpulkan bahwa tidak terdapat perbedaan kinerja secara signifikan antara indeks saham syariah dan indeks saham konvensional. Hasil penelitian yang dilakukan oleh Guerard (Guerard 1997), Hussein (Hussein 2004), Kreander dkk (Kreander et al. 2005), Albaity dkk (M. Albaity et al. 2008), Shloma (Shloma 2006), Hanafi (Hanafi and Hanafi 2012), Natarajan dkk (Natarajan and Dharani 2012), Rathner (Rathner 2013), Ho dkk (Ho et al. 2014), Reddy dan Fu (Reddy and Fu 2014), Utz dan Wimmer (Utz and Wimmer 2014), dan Ata dan Buğan (Ata and Buğan 2015) juga menunjukkan bahwa tidak ada perbedaan kinerja secara signifikan antara indeks saham syariah dan indeks saham konvensional. Penelitian kelompok kedua antara lain penelitian yang dilakukan oleh Bauer (Bauer, Otten, and Rad 2006), Mansor dan Bhatti (Mansor and Bhatti 2011) yang menjelaskan bahwa kinerja indeks saham konvensional lebih baik dibandingkan kinerja indeks saham syariah, dan penelitian yang dilakukan oleh Barau (Barau 2016) menunjukkan bahwa kinerja pasar saham konvensional di Gulf Cooperation Council (GCC) region lebih baik dibandingkan pasar saham syariah. Penelitian kelompok ke tiga antara lain penelitian yang dilakukan oleh Kurniawan dan Asandimitra (Kurniawan and Asandimitra 2014), yang menyatakan bahwa kinerja indeks syariah lebih baik dibandingkan kinerja indeks konvensional; serta penelitian Mallin dkk (Mallin, Saadouni, and Briston 1995), Miniaoui dkk (Miniaoui, Sayani, and Chaibi 2015), dan Sensoy (Sensoy 2016) yang menunjukkan bahwa indeks saham syariah memiliki risiko lebih rendah dibandingkan indeks saham konvensional. Dengan demikian, dapat disimpulkan bahwa masih terdapat perbedaan hasil dari kajian riset terdahulu.

Penelitian ini bertujuan untuk membandingkan kinerja portofolio saham antara indeks JII (syariah) dan LQ45 (nonsyariah) pada tahun 2013-2017. Perbandingan tersebut menggunakan risk-adjusted measurement, antara lain 
menggunakan indeks Sharpe, Treynor, dan Jensen alpha. Penelitian ini juga mengukur kedua indeks tersebut pada masa pemulihan perekonomian, serta mengukur kedua kinerja indeks tersebut terutama saat pelemahan perekonomian Indonesia, terutama di tahun 2015.

\section{Landasan Teori}

Investasi pada dasarnya merupakan suatu aktivitas penanaman modal saat ini dengan harapan menghasilkan keuntungan di masa yang akan datang (Tendelilin 2001). Investasi memiliki jenis yang beragam, mulai dari investasi di sektor riil sampai sektor keuangan. Sektor keuangan juga memiliki jenis yang beragam, mulai dari pasar uang sampai pasar modal. Pasar modal merupakan salah satu alternatif investasi dengan berbagai pilihan jenis instrument investasi, mulai dari saham dan turunan dari saham (derivative), obligasi maupun sukuk, dan juga reksadana (Jogiyanto 2003). Investasi saham memiliki manfaat atau keuntungan berupa dividen maupun capital gain. Keuntungan berupa dividen akan diperoleh jika investor menanamkan modalnya pada jangka waktu tertentu (jangka panjang), sedangkan capital gain akan diperoleh investor kapanpun (jangka pendek) dengan cara diperjualbelikan.

Pemilihan instrument investasi saham yang tepat, akan sangat menentukan apakah investor dapat memperoleh keuntungan atau tidak. Pemilihan instrument investasi jenis ini, didasarkan pada penilaian tertentu, terutama jika mengharapkan keuntungan yang lebih. Pada dasarnya aktivitas investasi didasarkan pada dua hal, yaitu return dan risk (Putra and Rahmanti 2013). Pengukuran imbal hasil (return) dan risiko ini disebut sebagai pengukuran kinerja saham. Pengukuran kinerja saham dapat dilakukan dengan dua cara, yaitu pengukuran kinerja pada aktiva tunggal dan pengukuran kinerja portofolio. Pengukuran kinerja portofolio dapat dilakukan melalui pengukuran saham multi sektoral pada suatu indeks tertentu. Indeks secara umum dapat didefiniskan sebagai kumpulan saham 
yang memiliki kriteria tertentu. Secara umum dapat dibedakan dalam dua jenis, yaitu indeks saham syariah dan indeks nonsyariah. Di Indonesia indeks syariah terdiri dari beberapa indeks, salah satunya adalah Jakarta Islamic Index (JII), sedangkan saham nonsyariah salah satunya adalah indeks LQ45 (Jogiyanto 2003). Indeks LQ45 merupakan suatu indeks yang terdiri dari 45 saham terpilih, sementara JII merupakan indeks yang terdiri dari 30 saham terpilih. Pada dasarnya dua indeks ini memiliki kriteria yang berbeda, terutama pada indeks JII. Kriteria saham syariah meliputi terbebas dari unsur riba, maysir, gharar, larangan seperti memproduksi barang haram, pornografi, dan alkohol (Reddy and Fu 2014).

Pengukuran kinerja portofolio saham secara umum menggunakan beberapa indeks pengukuran, yaitu indeks Sharpe, indeks Treynor, dan indeks Jensen alpha (Touiti 2017). Indeks Sharpe digunakan untuk mengukur kinerja pasar dengan mempertimbangkan standar deviasi tingkat pengembaliannya. Standar deviasi merupakan estimasi probabilitas antara return realisasi dan return yang diharapkan. Indeks Sharpe menggunakan standar deviasi return yang tercermin dari risiko total untuk melihat risiko. Perhitungan indeks Sharpe mengacu pada konsep capital market line sebagai benchmark, yaitu membagi premi risiko portfolio dengan standar deviasinya. Indeks Treynor merupakan pengukuran indeks kinerja portofolio dengan menggunakan rasio volatilitas berdasarkan risiko sistematis. Risiko sistematis merupakan risiko yang tetap ada meskipun diversifikasi sudah dilakukan seoptimal mungkin. Pendekatan ini berasumsi bahwa portofolio sudah terdiversifikasi dengan baik sehingga risiko yang relevan adalah risiko sistematis (beta). Beta digunakan untuk mengukur risiko pasar atas portofolio relatif terhadap risiko pasar. Perhitungan indeks Treynor dilakukan dengan cara imbal hasil portfolio dikurangi dengan imbal hasil bebas risiko dan dibagi dengan beta portofolio. Indeks Jensen alpha menggambarkan perbedaan tingkat return aktual terhadap return yang diharapkan. Dengan kata lain, indeks Jensen alpha merupakan pengukuran seberapa baik kinerja portofolio 
dibandingkan dengan portofolio pasar, ditunjukkan dengan hasil positif (B. Setiawan 2017).

Penelitian dengan fokus membandingkan antara indeks saham syariah dan nonsyariah dalam konteks pasar modal telah banyak dilakukan. Penelitian Ahmad dan Haslindar (Ahmad and Haslindar 2002), Hussein (Hussein 2004), Abdullah dkk (Abdullah, Hassan, and Mohamad 2007), Lobe dkk (Lobe, Rößle, and Walkshäusl 2012), Albaity dkk (M. Albaity et al. 2008), menunjukkan bahwa secara statistik tidak terdapat perbedaan yang signifikan antara kinerja indeks syariah dan indeks konvensional. Meskipun demikian, dapat terjadi perbedaan kinerja kedua indeks tersebut terutama pada periode saat pasar bear dan bull. Penelitian Hussein (Hussein 2004) menyatakan bahwa indeks Islam berjalan lebih baik selama periode pasar bull. Sementara, Abdullah dkk (Abdullah, Hassan, and Mohamad 2007) menyimpukan bahwa indeks syariah memiliki kinerja lebih baik, terutama pada saat pasar bear. Penelitian Lobe dkk. (Lobe, Rößle, and Walkshäusl 2012) menyimpulkan hasil yang sama sebagaimana penelitian oleh Hussein (Hussein 2004). Dengan demikian, indeks syariah menunjukkan kinerja yang rendah selama periode pasar bear dan memiliki kinerja yang lebih baik selama periode pasar bull. Di sisi lain, Alam dkk (Alam and Rajjaque 2010) menyimpulkan bahwa selama periode pelemahan ekonomi indeks syariah memiliki kinerja lebih baik. Hal yang sama juga dijelaskan oleh Ho dkk (Ho et al. 2014), yang menyimpukan bahwa sebagian besar indeks syariah memiliki kinerja yang lebih baik terutama selama periode krisis.

Penelitian yang dilakukan Lean dan Parsva (Hooi Lean and Parsva 2012) menyimpulkan bahwa selama periode krisis, indeks syariah memiliki kinerja negatif dan lebih berisiko sebagaimana indeks konvensional. Berbeda halnya dengan penelitian yang dilakukan oleh Sukmana dan Kholid (Sukmana and Kholid 2012) yang menyimpulkan bahwa indeks syariah memiliki risiko minimal, jika dibandingkan dengan indeks konvensional pada saat krisis. Berdasarkan kedua penelitian tersebut, walaupun memiliki perbedaan hasil 
dalam hal menilai kinerja indeks konvensional dan syariah, temuan mengenai bagaimana indeks syariah yang berkinerja lebih baik terutama pada masa krisis. Albaity dan Mudor (M. S. Albaity and Mudor 2012) melakukan penelitian tentang hubungan pengaruh antara indeks syariah dan konvensional di Malaysia. Penelitian tersebut menyimpulkan bahwa, dalam hal hubungan jangka panjang pada periode sebelum dan sesudah krisis, indeks syariah lebih banyak memiliki korelasi. Berdasarkan studi pustaka tersebut menunjukkan bahwa pada dasarnya kinerja kedua indeks tersebut tidak mengalami perbedaan yang signifikan, hanya saja ketika ditelusuri melalui perubahan siklus perekonomian memunculkan karakteristik yang berbeda diantara kedua indeks tersebut.

Hipotesis dalam penelitian ini adalah sebagai berikut:

$\mathrm{H}_{0}$ : $\quad$ Tidak terdapat perbedaan kinerja portofolio yang signifikan antara indeks saham syariah dan non syariah.

Ha : Terdapat perbedaan kinerja portofolio yang signifikan antara indeks saham syariah dan non syariah.

\section{Metode Penelitian}

\section{Jenis Penelitian}

Penelitian ini menggunakan pendekatan kuantitatif, dengan menggunakan uji beda. Uji ini dilakukan untuk mengkomparasikan kinerja portofolio saham syariah maupun konvensional. Uji komparasi ini dilakukan dengan cara membandingkan indeks kinerja saham yang diukur melalui tiga indikator yaitu indeks Sharpe, indeks Treynor, dan indeks Jensen alpha.

\section{Sumber Data}

Sumber data yang digunakan dalam penelitian ini adalah data sekunder. Data yang dimaksud dalam penelitian ini merupakan data berupa laporan keuangan yang diperoleh melalui website Bursa Efek Indonesia maupun 
website masing-masing perusahaan. Data tersebut diperoleh dari website: http://www.idx.co.id, http://www.bi.go.id, http://www.finance.yahoo.com, dan http://www.duniainvestasi.com, dan data pendukung lainnya yang diperoleh dari artikel-artikel pada internet ataupun perpustakaan berupa buletin, jurnal, dan penelitian lainnya yang terkait dan relevan dengan penelitian ini. Adapun data yang dimaksud dalam penelitian ini antara lain:

a. Data daftar emiten yang termasuk ke dalam LQ45 dan JII periode 20132017;

b. Data transaksi harga penutupan saham harian yang masuk dalam kriteria sampel guna menghitung return saham;

c. Data nilai LQ45 dan JII pada penutupan harian selama periode penelitian guna mengukur return pasar;

d. Data BI rate selama periode penelitian guna menghitung return bebas risiko;

e. Data lain yang terkait yang mendukung proses penelitian ini.

\section{Teknik Pengambilan Sampel}

Populasi dalam penelitian ini adalah seluruh perusahaan yang listing di Bursa Efek Indonesia, sedangkan sampel dalam penelitian ini merupakan perusahaan yang listing di Indeks LQ45 sebagai representasi dari saham konvensional/nonsyariah dan perusahaan yang listing pada indeks JII sebagai representasi dari saham syariah. Teknik pengambilan sampel dalam penelitian ini menggunakan metode purposive sampling, yang merupakan teknik pengambilan sampel dengan menggunakan kriteria tertentu. Kriteria pengambilan data yang digunakan antara lain: (a) Perusahaan yang listing di Bursa Efek Indonesia, (b) Perusahaan tersebut listing di indeks LQ45 dan JII, (c) Perusahaan tersebut listing selama periode penelitian, yaitu mulai tahun 2013-2017, (d) Perusahaan tersebut tidak melakukan corporate action selama periode penelitian, terutama yang mengakibatkan perubahan harga secara signifikan.

Economica: Jurnal Ekonomi Islam - Volume 8, Nomor 2 (2017) 


\section{Teknik Pengumpulan Data}

Penelitian ini menggunakan dua teknik (metode), yaitu metode studi pustaka dan metode dokumentasi. Metode pustaka dilakukan dalam rangka mengumpulkan berbagai referensi untuk memperkuat kerangka teori, sedangkan metode dokumentasi digunakan untuk mengumpulkan data-data yang diperlukan dalam penelitian. Data yang diperoleh melalui metode studi pustaka, meliputi sumber informasi dari bacaan yang berupa literatur perpustakaan berupa buku, jurnal penelitian, dan data lainnya yang sesuai. Sementara, data yang diperoleh melalui metode dokumentasi berupa catatan laporan keuangan dan data pendukung lain dalam rangka memperoleh data untuk diolah dan dianalisis.

\section{Definisi Operasional dan Pengukuran Variabel}

Pembentukan portofolio optimal dalam penelitian ini menggunakan model indeks tunggal. Model ini dikembangkan oleh William Sharpe di tahun 1963 dengan tujuan untuk menyederhanakan model Markowitz dalam membentuk portofolio optimal. Dalam model Markowitz dirumitkan dengan melibatkan terlalu banyak varian dan kovarian dalam menghitung risiko portofolio. Ide William Sharpe dalam menyederhanakan perhitungan portofolio dengan mengganti kovarian return antar aktiva dengan kovarian return aktiva dengan return indeks pasar, yang kemudian dari ide inilah nama model indeks tunggal tercipta. Secara matematis dapat ditulis dengan rumus sebagai berikut:

$$
\begin{gathered}
R_{i}=\alpha_{i}-\beta_{i} R_{m}+e_{i} \\
E\left(R_{i}\right)=\alpha_{i}+\beta_{i} E\left(R_{m}\right)
\end{gathered}
$$

$\mathrm{R}_{\mathrm{i}} \quad$ : return saham periode $\mathrm{t}$

$\alpha_{\mathrm{i}} \quad$ : nilai ekspektasi dari return saham yang independen terhadap return pasar 
$\beta_{\mathrm{i}} \quad$ : pengukur risiko sistematik (beta) yang merupakan koefisien yang mengukur perubahan $\mathrm{R}_{\mathrm{i}}$ akibat dari perubahan $\mathrm{R}_{\mathrm{m}}$

$\mathrm{R}_{\mathrm{m}} \quad$ : return pasar

$\mathrm{E}\left(\mathrm{R}_{\mathrm{m}}\right)$ : expected return pasar

$\mathrm{e}_{\mathrm{i}} \quad$ : kesalahan residu yang merupakan variabel acak dengan nilai ekspektasi sama dengan nol $\mathrm{E}\left(\mathrm{e}_{\mathrm{i}}\right)=0$

Pembentukan portofolio optimal dengan menggunakan metode indeks tunggal dapat dilihat pada Tabel 1. Perhitungan pada Tabel 1 akan digunakan sebagai dasar perhitungan kinerja portofolio indeks dengan menggunakan tiga pengukuran, yaitu: indeks Sharpe, Treynor, dan Jansen alpha.

Tabel 1. Membentuk Portofolio Optimal Metode Indeks Tunggal

\begin{tabular}{|c|c|c|c|}
\hline No & Variabel & Keterangan & Indikator \\
\hline \multicolumn{4}{|c|}{ Membentuk Portofolio Optimal Metode Indeks Tunggal } \\
\hline 1 & $\mathrm{R}_{\mathrm{i}}$ & $\begin{array}{l}\text { Menghitung return saham i pada } \\
\text { periode } t\end{array}$ & $\mathrm{R}_{\mathrm{i}}=\frac{P_{t}-P_{t-1}+D_{t}}{P_{t-1}}$ \\
\hline 2 & $E\left(R_{i}\right)$ & $\begin{array}{l}\text { Menghitung return saham i yang } \\
\text { diharapkan }\end{array}$ & $\mathrm{E}\left(\mathrm{R}_{\mathrm{i}}\right)=\frac{\sum_{t=1}^{n} R_{i t}}{n}$ \\
\hline 3 & $\mathrm{SD}_{\mathrm{i}}$ & Menghitung standard deviasi saham i & $\mathrm{SD}_{\mathrm{i}}=\frac{\sum_{t=1}^{n}\left[R_{i t}-E\left(R_{i}\right)\right]^{2}}{n}$ \\
\hline 4 & $\sigma_{i}^{2}$ & Menghitung varian saham i & $\sigma_{i}^{2}=\mathrm{SD}^{2}=\left[\frac{\sum_{t=1}^{n}\left[R_{i t}-E\left(R_{i}\right)\right]^{2}}{n}\right]^{2}$ \\
\hline 5 & $\mathrm{R}_{\mathrm{m}}$ & $\begin{array}{l}\text { Menghitung return indeks pasar JII } \\
\text { periode } t\end{array}$ & $\mathrm{R}_{\mathrm{m}}=\frac{J I I_{t}-J I I_{t-1}}{J I I_{t-1}}$ \\
\hline 6 & $E\left(R_{m}\right)$ & $\begin{array}{l}\text { Menghitung return indeks pasar JII yang } \\
\text { diharapkan }\end{array}$ & $\mathrm{E}\left(\mathrm{R}_{\mathrm{i}}\right)=\frac{\sum_{t=1}^{n} R_{i t}}{n}$ \\
\hline 7 & $\mathrm{SD}_{\mathrm{m}}$ & $\begin{array}{l}\text { Menghitung standard deviasi indeks } \\
\text { pasar JII }\end{array}$ & $\mathrm{SD}_{\mathrm{m}}=\frac{\sum_{t=1}^{n}\left[R_{m t}-E\left(R_{m}\right)\right]^{2}}{n}$ \\
\hline 8 & $\sigma_{m}^{2}$ & Menghitung varian indeks pasar JII & $\sigma_{m}^{2}=\left[\frac{\sum_{t=1}^{n}\left[R_{m t}-E\left(R_{m}\right)\right]^{2}}{n}\right]^{2}$ \\
\hline 9 & $\sigma_{\mathrm{im}}$ & $\begin{array}{l}\text { Menghitung kovarian saham i dengan } \\
\text { indeks pasar JII }\end{array}$ & $\sigma_{\text {im }}=\frac{\sum_{t=1}^{n}\left[\left(R_{i t}-E\left(R_{i}\right)\right) \cdot\left(R_{m t}-E\left(R_{m t}\right)\right)\right]}{n}$ \\
\hline 10 & $\beta_{i}$ & Menghitung nilai Beta saham i & $\beta_{\mathrm{i}}=\frac{\sigma_{i m}}{\sigma_{m}^{2}}$ \\
\hline 11 & $\alpha_{\mathrm{i}}$ & Menghitung nilai Alpha saham i & $\alpha_{\mathrm{i}}=E\left(R_{i}\right)-\beta_{i} \cdot E\left(R_{m}\right)$ \\
\hline 12 & $R_{f}$ & Menghitung return bebas risiko & $\mathrm{R}_{\mathrm{f}}=\frac{\sum_{t=1}^{n} B I_{\text {Rate }}}{n}$ \\
\hline 13 & $E R B_{i}$ & Menghitung excess return to beta & $E R B_{i}=\frac{E\left(R_{i}\right)-R B R}{\beta_{i}}$ \\
\hline
\end{tabular}

Economica: Jurnal Ekonomi Islam - Volume 8, Nomor 2 (2017) 
Ferry Khusnul Mubarok, Ahmad Ridho Darmawan

\begin{tabular}{|c|c|c|c|}
\hline 14 & $C_{i}$ & $\begin{array}{l}\text { Menghitung nilai C untuk menentukan } \\
\text { nilai cut-off. Biasanya nilai cut-off adalah } \\
\text { saham dengan nilai C paling besar }\end{array}$ & $C_{i}=\frac{\sigma_{m \sum_{j=1}^{i} A_{j}}^{2}}{1+\sigma_{m \sum_{j=1}^{2} B_{j}}^{i}}$ \\
\hline 15 & $W_{i}$ & $\begin{array}{l}\text { Menghitung proporsi (prosentase) } \\
\text { komposisi portofolio }\end{array}$ & $\begin{array}{c}W_{i}=\frac{Z_{i}}{\sum_{j=1}^{k} Z_{i}} \\
Z_{i}=\frac{\beta_{i}}{\sigma_{e i}^{2}}\left(E R B_{i}-C^{*}\right)\end{array}$ \\
\hline 16 & $\mathrm{R}_{\mathrm{p}}$ & Menghitung return portofolio & $\mathrm{R}_{\mathrm{p}}=\frac{R_{p t}-R_{p t-1}}{R_{p t-1}}$ \\
\hline 17 & $E\left(R_{p}\right)$ & $\begin{array}{l}\text { Menghitung return portofolio yang } \\
\text { diharapkan }\end{array}$ & $\mathrm{E}\left(\mathrm{R}_{\mathrm{p}}\right)=\frac{\sum_{t=1}^{n} R_{p t}}{n}$ \\
\hline 18 & $\sigma_{\mathrm{pm}}$ & $\begin{array}{l}\text { Menghitung kovarian portofolio dengan } \\
\text { indeks pasar JII }\end{array}$ & $\begin{array}{c}\sigma_{p m}= \\
\sum_{t=1}^{n}\left[\left(R_{p t}-E\left(R_{p}\right)\right) \cdot\left(R_{m t}-E\left(R_{m t}\right)\right)\right]\end{array}$ \\
\hline 19 & $\beta_{p}$ & Menghitung nilai Beta portofolio & $\beta_{p}=\frac{n_{p m}}{\sigma_{m}^{2}}$ \\
\hline
\end{tabular}

Kinerja portofolio diukur dengan membandingkan return rata-rata harian per minggu antar portofolio dengan menggunakan metode risk adjusted performance yang dikembangkan oleh Sharpe (Indeks Sharpe), Treynor (Indeks Treynor), dan Jensen (Indeks Jensen alpha); dengan rincian rumus perhitungan sebagai berikut:

Rumus perhitungan Indeks Sharpe

$$
S_{p}=\frac{R_{i}-R_{f}}{\alpha}
$$

Keterangan:

$S_{p}$ : indeks Sharpe.

$R_{i}$ : return portofolio atau tingkat pengembalian pasar pada periode $\mathrm{t}$.

$R_{f}$ : return bebas resiko tingkat bunga bebas resiko pada periode $t$.

$\alpha \quad$ : total resiko yaitu hasil jumlah dari resiko sistematik dan resiko

Rumus perhitungan Indeks Treynor

$$
T_{p}=\frac{R_{i}-R_{f}}{\beta}
$$

Keterangan:

$T_{p}$ : indeks Treynor. 
$R_{i} \quad$ : return portofolio atau tingkat pengembalian pasar pada periode t.

$R_{f}$ : return bebas resiko tingkat bunga bebas resiko pada periode $\mathrm{t}$.

$\beta \quad$ : risiko pasar dari portofolio atau risiko sistematik portofolio (koefisien beta pasar)

Rumus perhitungan Indeks Jansen alpha

Keterangan:

$$
a_{p}=R_{p}-\left[R_{f}+\beta_{p}\left(R_{m}-R_{f}\right)\right]
$$

$a_{p} \quad$ :indeks Jensen alpha

$R_{p}$ : return portofolio pada periode $\mathrm{t}$

$R_{f}$ : return pada investasi bebas resiko pada periode $\mathrm{t}$

$R_{m}: \beta_{p} /$ koefisien beta pasar.

\section{Teknik Analisis Data}

Kinerja portofolio antara indeks syariah dan nonsyariah dalam penelitian ini dibandingkan dengan menggunakan uji hipotesis komparatif (uji beda) rata-rata dua sampel (paired sample T-Test) dengan tingkat kesalahan yang ditolerir $(\alpha)$ sebesar 5\%. Pengujian hipotesis dilakukan dengan membandingkan nilai $t_{\text {hitung }}$ dengan nilai $t_{\text {tabel }}$. Apabila nilai $t_{\text {hitung }}$ lebih besar dibanding ttabel maka $\mathrm{H}_{0}$ diterima. Dengan kata lain, tidak terdapat perbedaan yang signifikan antara dua kelompok data yang diperbandingkan. Selain itu, analisis juga dilakukan dengan melihat nilai kemungkinan tingkat kesalahan (Pro Sig). Apabila nilai Pro Sig lebih kecil dari tingkat kesalahan yang telah ditetapkan (5\%) maka dapat dikatakan terdapat perbedaaan yang signifikan dari dua kelompok yang dibandingkan. Penelitian ini menggunakan uji beda dua pihak (two-tail) untuk menguji apakah ada perbedaan yang signifikan antara indeks saham syariah dan nonsyariah.

\section{Hasil dan Pembahasan}

\section{Kinerja Portofolio Saham Nonsyariah (LQ 45)}


Portofolio indeks saham konvensional yang terbentuk dari saham-saham yang konsisten listing pada indeks LQ45 dan tidak melakukan aksi korporasi berupa HMETD, Waran, dan Stock Split atau Reverse Stock selama periode 2013-2017, terdapat 22 saham yang memenuhi kriteria. Berdasarkan hasil pembentukan portofolio optimal dengan menggunakan metode indeks tunggal terdapat 7 saham terbaik, dengan proporsi antara lain: UNVR sebesar 20,72\%; BBCA sebesar 33,65\%; BBNI sebesar 17,38\%; BBRI sebesar 16,07\%; AKRA 4,42\%; UNTR 5,50\%; dan INCO sebesar 2,25\%. Kontribusi kinerja per sektor pada indeks LQ45 dapat dilihat pada Gambar 1.

Gambar 1. Persentase Kontribusi Per Sektor Indeks LQ45

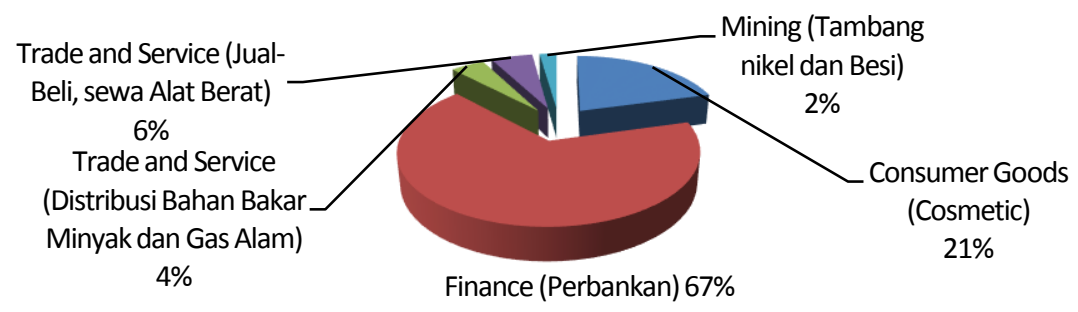

Berdasarkan perhitungan, kinerja portofolio yang terbentuk menghasilkan tingkat return sebesar 140,36\% selama periode 2013-2017; dengan asumsi bahwa saham-saham yang masuk ke dalam portofolio tersebut sesuai dengan proporsinya, yang disimpan dari awal tahun 2013 dan dijual pada akhir 2017. Tingkat return tersebut memiliki risiko portofolio yang diukur menggunakan nilai standar deviasi portofolio sebesar 4,26\% dengan nilai beta sebesar $104,55 \%$.

Gambar 2 menunjukkan bahwa hasil penilaian kinerja portofolio dengan menggunakan return bulanan dan dibandingkan dengan kinerja return bulanan indeks LQ45, membentuk pola yang sama dan memberikan gambaran bahwa portofolio yang terbentuk dipengaruhi oleh kinerja indeks pasar. Hal ini sejalan dengan teori pembentukan portofolio optimal dengan menggunakan metode indeks tunggal. Namun demikian, beberapa kinerja 
portofolio memberikan nilai di atas kinerja indeks pasar terutama pada saham-saham tertentu. Kinerja portofolio saham-saham nonsyariah yang didasarkan pada indeks LQ45 memberikan hasil yang berbeda setiap tahunnya. Jika dinilai lebih dalam, maka kinerja portofolio tersebut memiliki tingkat return terendah di tahun 2015, sebagai titik tengah dari periode pengukuran kinerja selama 2013-2017.

Gambar 2. Hasil Penilaian Kinerja Portofolio Bulanan Indeks LQ45

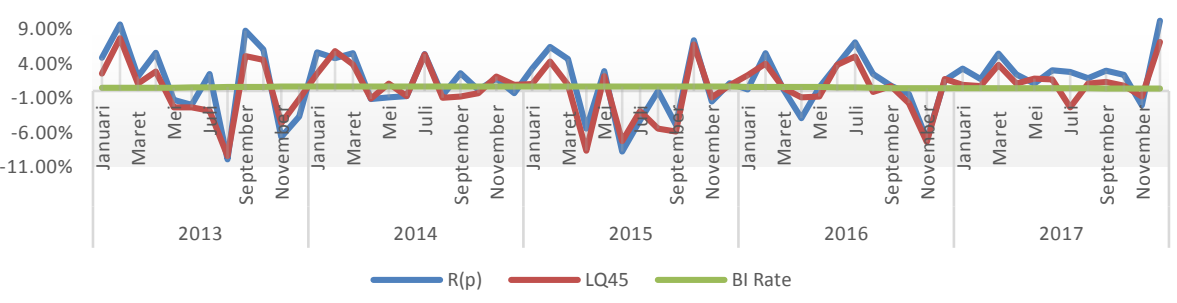

Gambar 3. Return Portofolio Indeks LQ45

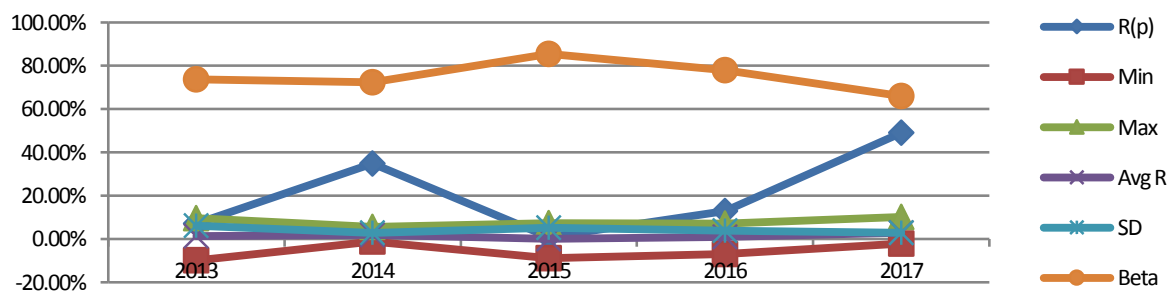

Tahun 2013 merupakan tahun perbaikan kondisi ekonomi global pasca krisis keuangan, dimana kondisi perekonomian di beberapa negara maju mengalami pemulihan. Gambar 3 menunjukkan bahwa kinerja portofolio 2014 mengalami peningkatan dibanding tahun sebelumnya. Hal ini juga didukung dengan nilai risiko total serta nilai beta yang mengalami penurunan terutama dalam mendukung kinerja return. Di tahun 2015 kinerja return portofolio mengalami penurunan sangat signifikan, yang ditandai adanya selisih penurunan return di tahun 2015 lebih tinggi dibandingkan dengan selisih peningkatan kinerja return portofolio di tahun 2014. Kinerja portofolio

Economica: Jurnal Ekonomi Islam - Volume 8, Nomor 2 (2017) 
tahun 2015 tersebut sangat dipengaruhi oleh risiko sistematik atau disebut juga risiko makroekonomi. Kondisi makroekonomi di tahun 2015 terdapat perubahan kebijakan, terutama negara-negara maju yang sedang dalam masa pemulihan perekonomiannya.

Dampak krisis keuangan global 2008, juga menjadi salah satu faktor yang menyebabkan pasar komoditas global mengalami ketidakstabilan harga. Faktor ini juga memengaruhi kondisi perekonomian negara berkembang salah satunya Indonesia, terutama berdampak terhadap tingkat risiko portofolio yang dibentuk. Kinerja portofolio yang terbentuk di tahun 2015 memiliki kontribusi cukup besar terhadap tingkat risikonya, yaitu nilai beta sebesar $85,47 \%$ dengan nilai risiko portofolio sebesar 5,1\%. Dilihat dari kinerja return yang diperoleh, pengaruh risiko makroekonomi memberi dampak signifikan yaitu dengan adanya penurunan kinerja portofolio sebesar 33,94\% menjadi 0,86\%. Kondisi makroekonomi di tahun 2016 dan 2017 mengalami pemulihan, ditandai dengan stabilitas harga komoditas global dan upaya kebijakan pemerintah dalam mengantisipasi kondisi perekonomian global. Tahun 2016 nilai Beta yang turun dari 7,39\% menjadi 78,01\%, dan 19,4\% menjadi 66\% di tahun 2017, dan tingkat risiko yang turun 1,29\% di tahun 2016 dan 2,23\% di tahun 2017. Dengan demikian, dampaknya adanya peningkatan kembali return portofolio yang cukup signifikan di tahun 2016 dan 2017 yaitu masing-masing sebesar 12,86\% dan 48,99\%.

\section{Kinerja Portofolio Saham Syariah (Jakarta Islamic Index)}

Portofolio indeks saham syariah terbentuk dari saham-saham yang konsisten listing di JII, dan tidak melakukan aksi korporasi berupa HMETD, Waran, dan Stock Split atau Reverse Stock selama periode 2013-2017 terdapat 12 saham yang memenuhi kriteria. Berdasarkan hasil pembentukan portofolio optimal dengan menggunakan metode indeks tunggal, terbentuk 5 
saham terbaik dengan proporsi sebagai berikut: UNVR sebesar 56,10\%; AKRA sebesar 12,30\%; UNTR sebesar 15,44\%; KLBF sebesar 12,27\%; dan ADRO sebesar 3,89\%. Kontribusi kinerja saham sektoral pada indeks JII dapat dilihat pada Gambar 4.

Gambar 4. Persentase Kontribusi Per Sektor Indeks JII

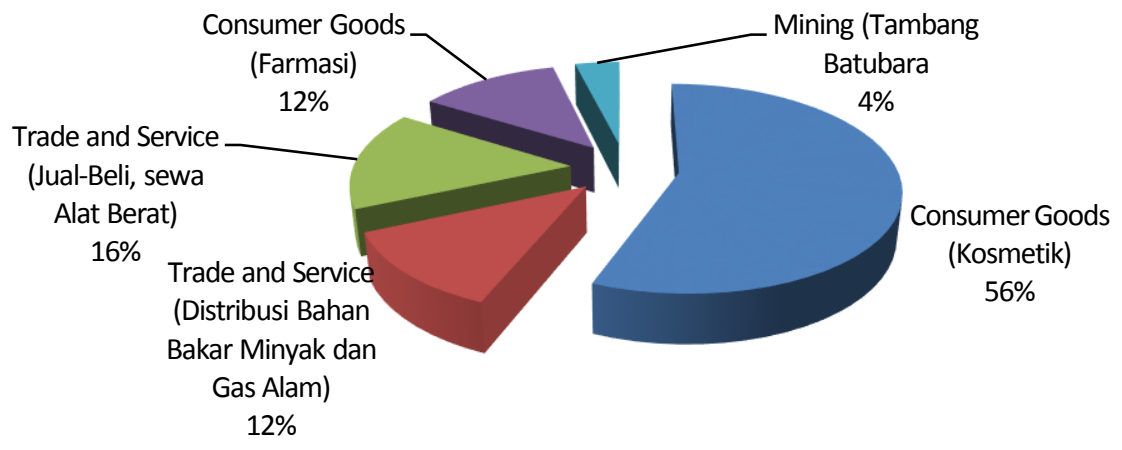

Berdasarkan perhitungan, kinerja portofolio yang terbentuk menghasilkan return sebesar 112,65\% selama periode 2013-2017, dengan asumsi bahwa saham-saham yang masuk dalam portofolio tersebut sesuai dengan proporsinya yang disimpan di awal tahun 2013 dan dijual pada akhir 2017. Dengan tingkat risiko portofolio yang diukur dengan menggunakan nilai standar deviasi portofolio sebesar 4,04\% dengan nilai beta $69,8 \%$.

Gambar 5. Perbandingan Indeks JII dengan Kinerja Indeks Pasar 


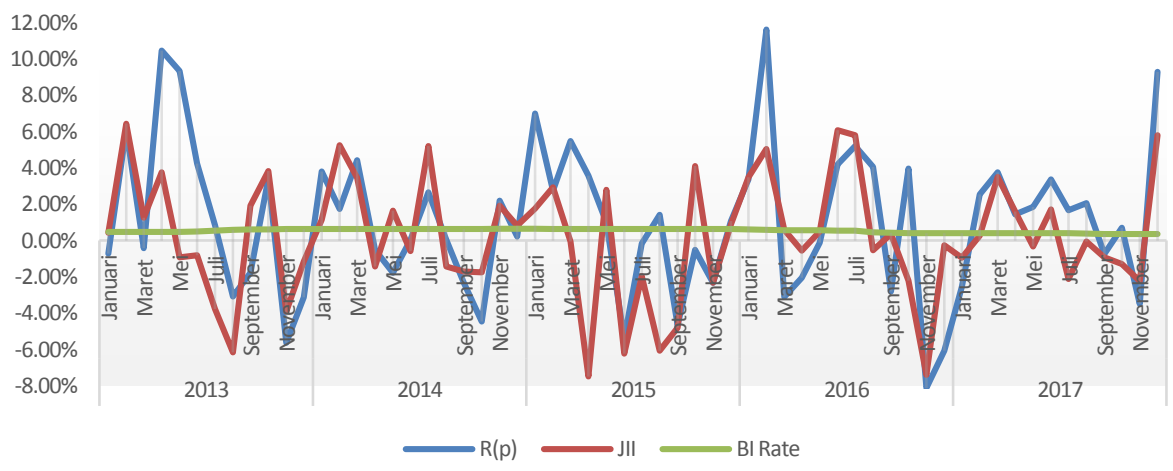

Gambar 5 menunjukkan bahwa hasil penilaian kinerja portofolio return bulanan indeks JII membentuk pola pergerakan yang hampir sama dengan pergerakan indeks pasar. Hal ini berarti bahwa portofolio yang dibentuk sangat dipengaruhi oleh kinerja indeks pasar, sesuai dengan teori pembentukan portofolio optimal dengan menggunakan metode indeks tunggal. Namun demikian, di beberapa titik tertentu kinerja portofolio JII di atas kinerja indeks pasar. Kinerja portofolio saham syariah tersebut memberikan hasil yang berbeda di tiap tahunnya. Jika dinilai lebih dalam, maka kinerja portofolio tersebut memiliki tingkat return terendah di tahun 2015, sebagai titik tengah dari periode pengukuran kinerja selama 20132017.

Gambar 6. Kinerja Portofolio Indeks JII

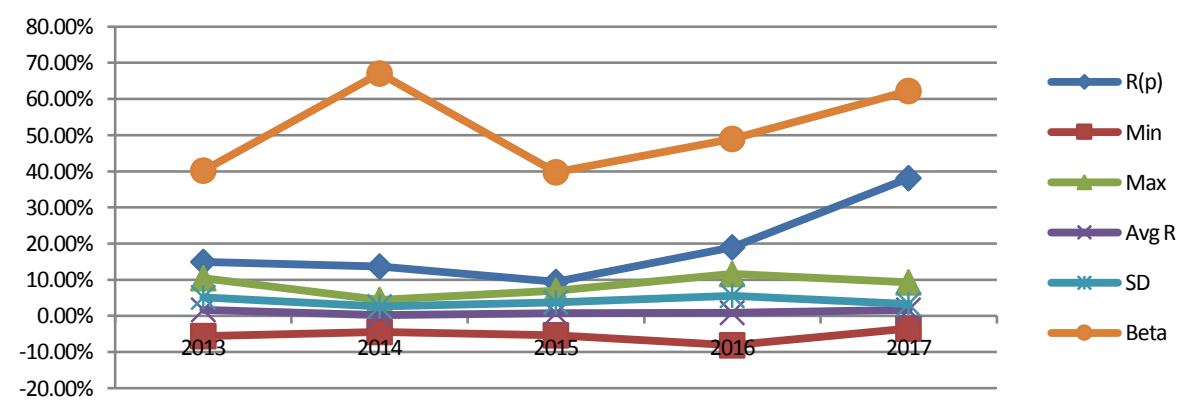


Kinerja portofolio indeks JII pada Gambar 6 memiliki nilai yang berbeda, terutama jika dibandingkan dengan kinerja portofolio saham-saham LQ45. Terlihat di tahun 2013 hasil return portofolio berada di angka 14,95\% dengan tingkat risiko sebesar 5,11\% dan nilai beta 40,17\%. Kinerja ini dinilai lebih baik dibandingkan dengan kinerja portofolio indeks LQ45. Di tahun 2014, kinerja portofolio ini mengalami penurunan return menjadi 13,61\%, menurun sebesar 1,34\%, akan tetapi nilai return yang menurun diikuti dengan tingkat risiko yang menurun pula, yakni sebesar 2,6\%. Di sisi lain, nilai beta sebagai risiko sistematik memberikan pengaruh risiko yang cukup signifikan yaitu sebesar 67,09\%. Tahun 2015 yang merupakan tahun di mana kinerja pertumbuhan ekonomi Indonesia dan dunia mengalami pelemahan, kinerja portofolio yang dibentuk oleh indeks JII lebih baik jika dibandingkan dengan kinerja portofolio yang dibentuk indeks LQ45. Di mana kinerja return-nya hanya menurun sebesar 4,18\% menjadi 9,43\%. Jika dilihat dari tingkat risiko portofolio, mengalami peningkatan menjadi 3,73\%, namun dengan pengaruh nilai beta yang menurun menjadi 39,74\%.

Tahun 2016 dan 2017, kinerja portofolio mengalami peningkatan cukup signifikan. Return portofolio di tahun 2016 mengalami peningkatan kinerja sebesar 18,96\% dan di tahun 2017 sebesar 38,1\%. Peningkatan kinerja return ini dibarengi dengan tingkat risiko yang berbeda. Di mana tingkat risiko di tahun 2016 mengalami peningkatan menjadi 5,55\% dan nilai beta 48,89\%. Sementara itu, di tahun 2017 tingkat risiko mengalami penurunan menjadi $3,27 \%$ dengan nilai beta yang meningkat menjadi $62,25 \%$. Hasil ini memberikan kesimpulan bahwa portofolio yang dibentuk indeks JII lebih tahan terhadap risiko, atau dapat dikatakan lebih meminimalisir risiko. Sedangkan jika dilihat dari pola nilai beta yang dihasilkan, menunjukkan kemungkinan bahwa portofolio yang terbentuk terlambat merespon risiko, terutama terhadap kondisi makroekonomi. 


\section{Perbandingan Kinerja Portofolio Saham Syariah dan Saham Nonsyariah}

Perbadingan kinerja portofolio antara saham syariah dan non syariah menggunakan uji T (paired sample T-test), yang mendasarkan pada nilai riskadjusted performance yang terdiri dari Indeks Sharpe, Indeks Treynor dan Indeks Jensen alpha. Adapun rumus pengujian hipotesisnya adalah sebagai berikut:

$\mathrm{H}_{0}: \mu 1=\mu 2$ : Tidak terdapat perbedaan signifikan kinerja portofolio antara saham syariah dan non syariah

Ha: $\mu 1 \neq \mu 2$ : Terdapat perbedaan signifikan kinerja portofolio antara saham syariah dan non syariah

Sehingga kriteria dalam pengujian ini adalah:

$\mathrm{H}_{0}$ diterima jika sig-t (probabilitas) $>0,05$ atau $\mathrm{t}$ hitung $\leq \mathrm{t}$ tabel atau $-\mathrm{t}$ hitung $\geq$-t tabel.

$\mathrm{H}_{0}$ ditolak jika sig-t (probabilitas) $<0,05$ atau $\mathrm{t}$ hitung $\geq \mathrm{t}$ tabel atau $-\mathrm{t}$ hitung $\leq-\mathrm{t}$ tabel.

Tabel 2. Hasil Perbandingan Nilai Indeks Sharpe

\begin{tabular}{|c|c|c|c|c|c|c|c|c|c|}
\hline & & & & ired Samples & Test & & & & \\
\hline & & & & ired Differen & & & & & \\
\hline & & & Std. & Std. Error & $\begin{array}{l}95 \% \text { Confide } \\
\text { of the } \mathrm{Di}\end{array}$ & $\begin{array}{l}\text { Interval } \\
\text { ence }\end{array}$ & & & Sig. (2- \\
\hline ir 1 & LQ45 - JII & $\begin{array}{c}\text { Mean } \\
.0676545\end{array}$ & $\begin{array}{l}\text { Deviation } \\
.9280081\end{array}$ & $\begin{array}{l}\text { Mean } \\
.1198053\end{array}$ & $\begin{array}{l}\text { Lower } \\
-.1720754\end{array}$ & $\begin{array}{l}\text { Upper } \\
.3073844\end{array}$ & $\begin{array}{c}\mathrm{t} \\
.565\end{array}$ & $\begin{array}{l}\text { Df } \\
59\end{array}$ & $\begin{array}{r}\text { tailed) } \\
.574\end{array}$ \\
\hline
\end{tabular}

Hasil dari uji t perbandingan kinerja portofolio menggunakan indeks Sharpe antara saham syariah dan nonsyariah menunjukkan bahwa nilai signifikan sebesar 0,574 > sig. t sebesar 0,05 dan nilai t hitung sebesar 0,565 < t tabel sebesar 2,000. Hasil ini menunjukkan bahwa diterimanya $\mathrm{H}_{0}$ dan menolak Ha, atau dapat dikatakan tidak terjadi perbedaan signifikan antara kedua indeks tersebut. 
Tabel 3. Hasil Perbandingan Nilai Indeks Treynor

\begin{tabular}{|c|c|c|c|c|c|c|c|c|c|}
\hline \multicolumn{10}{|c|}{ Paired Samples Test } \\
\hline & & \multicolumn{5}{|c|}{ Paired Differences } & \multirow{2}{*}{\multicolumn{3}{|c|}{ Sig. (2- }} \\
\hline & & \multirow{3}{*}{$\begin{array}{c}\text { Mean } \\
.0004634\end{array}$} & \multirow{3}{*}{$\begin{array}{c}\text { Std. } \\
\text { Deviation } \\
.0482522\end{array}$} & \multicolumn{3}{|c|}{ 95\% Confidence Interval } & & & \\
\hline & & & & Mean & Lower & Upper & $\mathrm{t}$ & df & tailed) \\
\hline Pair 1 & LQ45 - JII & & & .0062293 & -.0120015 & .0129282 & .074 & 59 & .941 \\
\hline
\end{tabular}

Hasil dari uji t perbandingan kinerja indeks Treynor antara kedua kinerja portofolio tersebut, menunjukkan bahwa nilai signifikan sebesar 0,941 > sig. t sebesar 0,05 dan nilai $\mathrm{t}$ hitung sebesar 0,074< t tabel sebesar 2,000. Berdasarkan hasil ini, maka disimpulkan bahwa $\mathrm{H}_{0}$ diterima dan menolak Ha, atau dengan kata lain tidak mengalami perbedaan signifikan.

Tabel 4. Hasil Perbandingan Nilai Indeks Jensen alpha

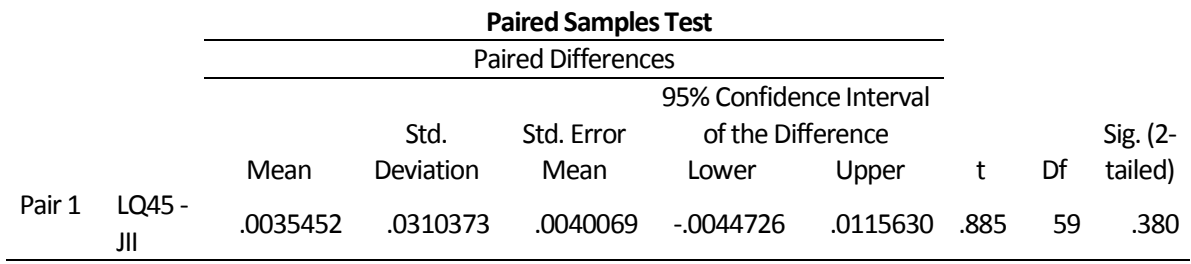

Tabel 4 menunjukkan bahwa perbandingan kinerja indeks Jensen alpha antara kinerja portofolio saham syariah dan nonsyariah terdapat nilai signifikansi sebesar 0,885 > sig. t sebesar 0,05 dan nilai thitung sebesar 0,380 $<\mathrm{t}$ tabel sebesar 2,000. Berdasarkan hasil tersebut, maka dapat disimpulkan bahwa $\mathrm{H}_{0}$ diterima dan menolak $\mathrm{Ha}$, dengan kata lain tidak terdapat perbedaan yang signifikan.

Berdasarkan ketiga hasil uji t tersebut, maka dapat disimpulkan bahwa kinerja portofolio saham syariah dan nonsyariah tidak terdapat perbedaan signifikan. Meskipun demikian, hal ini nampak berbeda jika dilihat dari sisi return, standard deviasi, nilai beta, dan juga saham mayoritas yang masuk ke dalam portofolio.

Economica: Jurnal Ekonomi Islam - Volume 8, Nomor 2 (2017) 
Gambar 7. Perbandingan Kinerja Indeks JII dan LQ45

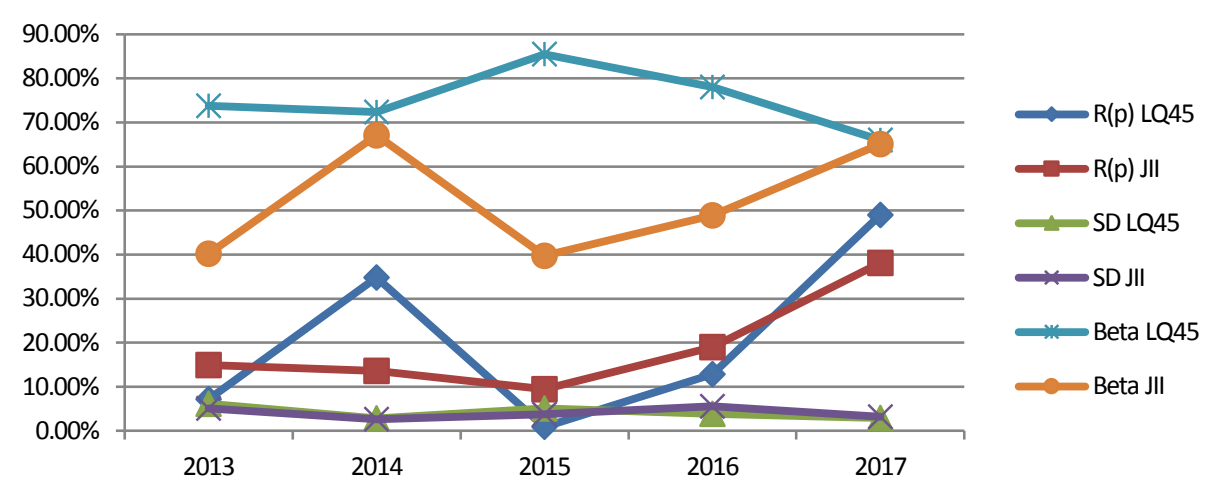

Gambar 7 menunjukkan bahwa nilai beta antara portofolio LQ45 dan JII memiliki perbedaan signifikan di tahun 2013, 2015 dan 2016. Jika merujuk pada tingkat risiko yang diukur dengan menggunakan nilai standard deviasi yang sama, menghasilkan return yang berbeda walaupun tidak signifikan. Portofolio JII di tahun 2013 menghasilkan return lebih besar 7,79\%, tahun 2014 portofolio LQ45 menghasilkan return lebih besar 21,19\%, tahun 2015 portofolio JII menghasilkan return lebih besar 8,57\%, tahun 2016 portofolio JII menghasilkan return lebih besar 6,1\% dan pada tahun 2017 return portofolio LQ45 lebih besar 10,89\%. Kinerja tersebut menunjukkan bahwa portofolio yang dibentuk indeks JII memiliki kemampuan yang lebih baik dalam meminimalkan risiko sistematik dibandingkan dengan portofolio yang dibentuk oleh indeks LQ45. Di sisi yang lain, kinerja portofolio LQ45 memberikan respon return yang lebih baik, terutama pada masa pemulihan perekonomian. Hal ini nampak pada kinerja portofolio LQ45 di tahun 2014 dan tahun 2017, dampak membaiknya perekonomian global dan regional memiliki pengaruh signifikan. Jika mendasarkan pada sektor, sektor saham mayoritas yang paling berpengaruh terhadap kinerja portofolio LQ45 adalah sektor finance, dengan bidang usaha perbankan. Sementara, kinerja portofolio JII adalah sektor consumer goods, dengan bidang usaha kosmetik. 
Optimalisasi Portofolio Nilai Saham ...

\section{Pembahasan}

Hasil analisis menunjukkan bahwa tidak terdapat perbedaan kinerja portofolio antara indeks LQ45 dan JII. Ini sejalan dengan penelitian Guerard (Guerard 1997), Hussein (Hussein 2004), Kreander dkk (Kreander et al. 2005), Albaity dkk (M. Albaity et al. 2008), Shloma (Shloma 2006), Hanafi (Hanafi and Hanafi 2012), Natarajan dan Dharani (Natarajan and Dharani 2012), Rathner (Rathner 2013), Setiawan dan Oktariza (C. Setiawan and Oktariza 2013), Ho dkk (Ho et al. 2014), Reddy dan Fu (Reddy and Fu 2014), dan Utz dan Wimmer (Utz and Wimmer 2014), Pranata dan Nurzanah (Pranata and Nurzanah 2015), serta Ata dan Buğan (Ata and Buğan 2015) yang menyimpulkan bahwa tidak terdapat perbedaan kinerja secara signifikan antara indeks saham syariah dan indeks saham konvensional.

Dari hasil tersebut, muncul pertanyaan mendasar mengapa tidak terdapat perbedaan di antara kedua indeks tersebut. Pada dasarnya bahwa saham-saham yang listing pada indeks-indeks tersebut, di beberapa saham tertentu sama-sama listing pada dua indeks tersebut. Meskipun demikian, ada beberapa saham yang tidak dapat listing pada indeks JII, terutama disebabkan tidak terpenuhinya kriteria untuk listing pada indeks saham syariah.

Meskipun tidak memiliki perbedaan signifikan, kedua indeks tersebut memiliki karakteristik yang berbeda terutama terhadap perubahan siklus dalam perkekonomian. Berdasarkan hasil penelitian, indeks saham syariah memiliki karakteristik terutama ketahanan terhadap krisis yang lebih baik dibandingkan dengan indeks saham konvensional. Hal ini ditunjukkan dengan adanya return yang lebih besar pada indeks JII, terutama saat pelemahan ekonomi di tahun 2015. Hal ini sejalan dengan penelitian yang dilakukan oleh Touiti (Touiti 2017), yang menyimpulkan bahwa kinerja indeks syariah lebih baik daripada indeks konvensional pada saat krisis. Hal yang sama juga dungkapkan oleh Mehmood et al (Mehmood, Akhter, and Shahbaz 2016), yang mengungkap bahwa kinerja saham syariah dapat dijadikan instrumen hedging karena memiliki kinerja yang lebih baik terhadap krisis keuangan.

Economica: Jurnal Ekonomi Islam - Volume 8, Nomor 2 (2017) 
Di samping itu, kinerja saham juga dapat diukur melalui tingkat risikonya, semakin kecil risikonya maka semakin baik kinerjanya. Sukmana dan Kholid (Sukmana and Kholid 2012) menjelaskan bahwa risiko indeks syariah lebih kecil dibanding konvensional terutama pada saat terjadi krisis.

Berbeda halnya dengan indeks syariah yang cukup baik pada saat krisis terjadi, indeks konvensional memiliki kelebihan terutama pada saat pemulihan perekonomian. Berdasarkan hasil analisis tersebut menunjukkan bahwa kinerja LQ45 lebih baik dibandingkan dengan indeks JII. Hal ini diperkuat dengan hasil penelitian Mansor dan Bhatti (Mansor and Bhatti 2011) yang menyimpulkan bahwa kinerja indeks saham konvensional lebih baik dibandingkan kinerja indeks saham syariah. Demikian juga penelitian yang dilakukan Barau (Barau 2016) menyebutkan bahwa kinerja pasar saham konvensional di Gulf Cooperation Council (GCC) region lebih baik dibandingkan pasar saham syariah.

\section{Simpulan}

Berdasarkan hasil analisis dan pembahasan di atas, maka dapat disimpulkan bahwa kinerja portofolio saham antara indeks LQ45 dan JII secara keseluruhan tidak memiliki perbedaan yang signifikan. Pengukuran ini didasarkan pada Risk Adjusted Performance, yaitu dengan menggunakan indeks Sharpe, Treynor, dan Jansen alpha. Jika dibandingkan berdasarkan data tahunan, maka kinerja portofolio JII lebih tahan terhadap kondisi makroekonomi yang kurang stabil, sedangkan kinerja portofolio LQ45 memiliki respon kinerja yang lebih baik terhadap kondisi makroekonomi terutama pada masa pemulihan. Pada dasarnya indeks LQ45 merupakan indeks 45 saham terbaik, baik secara kapitalisasi pasar maupun frekuensi perdagangan, sedangkan indeks JII merupakan indeks 30 saham yang sangat ketat dalam kualifikasi label syariah, di samping menilai kapitalisasi pasar dan frekuensi perdagangan. Namun demikian, membandingkan kedua indeks tersebut pada dasarnya tidak berbeda secara signifikan, karena terdapat 
beberapa saham yang sama-sama masuk ke dalam dua indeks tersebut, walaupun ada beberapa saham yang tidak masuk dalam indeks JII karena tidak memenuhi prinsip-prinsip syariah.

\section{Daftar Pustaka}

Abdullah, Fikriyah, Taufiq Hassan, and Shamsher Mohamad. 2007. "Investigation of Performance of Malaysian Islamic Unit Trust Funds." Managerial Finance 33 (2). Emerald Group Publishing Limited: 142-53. https://doi.org/10.1108/03074350710715854.

Ahmad, Zamri, and Ibrahim Haslindar. 2002. "AStudy of the Performance of the KLSE Syari'ah Index." Malaysian Management Journal 6 (1 \& 2): 25-34. http://mmj.uum.edu.my/index.php/previous-issues/127-malaysianmanagement-journal-mmj-vol-6-no-1-2-june-december-2002.

Alam, Nafis, and Mohammad Shadique Rajjaque. 2010. "Shariah-Compliant Equities: Empirical Evaluation of Performance in the European Market during Credit Crunch." Journal of Financial Services Marketing 15 (3). Palgrave Macmillan UK: 228-40. https://doi.org/10.1057/fsm.2010.19.

Albaity, Mohamed, Rubi Ahmad, Mohamed Albaity, and Rubi Ahmad. 2008. "Performance of Syariah and Composite Indices: Evidence from Bursa Malaysia." Asian Academy of Management Journal of Accounting and Finance (AAMJAF) 4 (1). Penerbit Universiti Sains Malaysia: 23-43. https://econpapers.repec.org/article/usmjournl/aamjaf00401_5f2343.htm.

Albaity, Mohamed Shikh, and Hamdia Mudor. 2012. "Return Performance, Cointegration and Short Run Dynamics of Islamic and Non-Islamic Indices: Evidence from the US and Malaysia during the Subprime Crisis." Economic Analysis Working Papers (2002-2010). Atlantic Review of Economics (2011-2016) 1. Colexio de Economistas de ACoruña, Spain and Fundación Una Galicia Moderna: 1-1. https://ideas.repec.org/a/eac/ articl/08-11.html.

Ata, H. Ali, and Mehmet Fatih Buğan. 2015. "Comparison of the Performances Islamic and Conventional Market Indices and Their Causal Relationship." International Journal of Business Management and Economic Research(IJBMER) 6 (6): 455-62. 
Ferry Khusnul Mubarok, Ahmad Ridho Darmawan

Barau, Ahmad Mohammad. 2016. "Did Islamic Equities Outperform Conventional Equities In the Gulf Cooperation Council (GCC) Region During and After the Global Financial Crisis?" Research Journal of Finance and Accounting 7 (8): 200-210. http://iiste.org/Journals/index.php/ RJFA/article/view/30004.

Bauer, Rob, Rogér Otten, and Alireza Tourani Rad. 2006. "Ethical Investing in Australia: Is There a Financial Penalty?" Pacific-Basin Finance Journal 14 (1). North-Holland: 33-48.

Derigs, Ulrich, and Shehab Marzban. 2009. "New Strategies and a New Paradigm for Shariah-Compliant Portfolio Optimization." Journal of Banking \& Finance 33 (6). North-Holland: 1166-76. https://doi.org/ 10.1016/J.JBANKFIN.2008.12.011.

Guerard, John B.. 1997. "Is There a Cost to Being Socially Responsible in Investing?" The Journal of Investing 6 (2). Institutional Investor Journals Umbrella: 11-18. https://doi.org/10.3905/joi.1997.408416.

Hanafi, M. M, and S. M Hanafi. 2012. "Perbandingan Kinerja Investasi Syariah Dan Konvensional: Studi Pada Jakarta Islamic Indeks (JII) Dan Indeks LQ45." EKBISI 7 (1).

Ho, Catherine Soke Fun, Nurul Afiqah Abd Rahman, Noor Hafizha Muhamad Yusuf, and Zaminor Zamzamin. 2014. "Performance of Global Islamic versus Conventional Share Indices: International Evidence." Pacific-Basin Finance Journal 28 (June). North-Holland: 110-21. https://doi.org/ 10.1016/J.PACFIN.2013.09.002.

Hooi Lean, Hooi, and Parham Parsva. 2012. "Performance of Islamic Indices in Malaysia FTSE Market: Empirical Evidence from CAPM." Journal of Applied Sciences 12 (12): 1274-81. https://doi.org/10.3923/ jas.2012.1274.1281.

Hussein, Khaled A. 2004. "Ethical Investment: Empirical Evidence From Ftse Islamic Index." Islamic Economic Studies 12-1. The Islamic Research and Training Institute (IRTI): 22-40. https://ideas.repec.org/a/ris/ isecst/0066.html.

Jogiyanto. 2003. Teori Portofolio Dan Analisis Investasi, Edisi III. Cet. I. Yogyakarta: BPFE.

Kreander, N., R.H. Gray, D.M. Power, and C.D. Sinclair. 2005. "Evaluating the Performance of Ethical and Non-Ethical Funds: A Matched Pair Analysis." 
Journal of Business Finance \& Accounting 32 (7-8). Wiley/Blackwell (10.1111): 1465-93. https://doi.org/10.1111/j.0306-686X.2005.00636.x.

Kurniawan, Rizki Dwi, and Nadia Asandimitra. 2014. "Analisis Perbandingan Kineja Indeks Saham Syariah Dan Kinerja Indeks Saham Konvensional." Jurnal Ilmu Manajemen 2 (4): 1354-66.

Lobe, Sebastian, Felix Rößle, and Christian Walkshäusl. 2012. "The Price of Faith: Performance, Bull and Bear Markets, and Screening Effects of Islamic Investing Around the Globe." The Journal of Investing 21 (4). Institutional Investor Journals Umbrella: 153-64. https://doi.org/ 10.3905/joi.2012.21.4.153.

Mallin, C.A., B. Saadouni, and R.J Briston. 1995. "The Financial Performance of Ethical Investment Funds." Journal of Business Finance \& Accounting 22 (4). Wiley/Blackwell (10.1111): 483-96. https://doi.org/10.1111/ j.1468-5957.1995.tb00373.x.

Mansor, Fadillah, and M. Ishaq Bhatti. 2011. "Risk and Return Analysis on Performance of the Islamic Mutual Funds: Evidence from Malaysia." Global Economy and Finance Journal 4 (1): 19-31.

Mehmood, Khalid, Waheed Akhter, and Muhammad Shahbaz. 2016. "Performance of Islamic vs . Conventional Capital Markets during Global Financial Crisis: An Empirical Study Global Financial Crisis: An Empirical Study." https://doi.org/https://doi.org/10.13140/RG.2.2.10782.33606.

Miniaoui, Hela, Hameedah Sayani, and Anissa Chaibi. 2015. "The Impact Of Financial Crisis On Islamic And Conventional Indices Of The GCC Countries." Journal of Applied Business Research (JABR) 31 (2): 357. https://doi.org/10.19030/jabr.v31i2.9171.

Natarajan, P., and M. Dharani. 2012. "Shariah Compliant Stocks in India - A Viable and Ethical Investment Vehicle." https://papers.ssrn.com/sol3/ papers.cfm?abstract_id=2148902.

Pranata, Nika, and Nurzanah Nurzanah. 2015. "Conventional and Islamic Indices in Indonesia: A Comparison on Performance, Volatility, and the Determinants." Indonesian Capital Market Review 7 (2): 113-27. https://doi.org/10.21002/icmr.v7i2.5004.

Putra, Dwi, and Wiwin Rahmanti. 2013. "Return Dan Risiko Saham Pada Perusahaan Perata Laba Dan Bukan Perata Laba." Jurnal Dinamika Akuntansi 5 (1). https://doi.org/10.15294/jda.v5i1.2563. 
Rathner, Sebastian. 2013. "The Relative Performance of Socially Responsible Investment Funds. New Evidence from Austria." Working Papers in Economics, March. University of Salzburg. https://ideas.repec.org/p/ris/ sbgwpe/2013_001.html.

Reddy, Krishna, and Mingli Fu. 2014. "Does Shariah Compliant Stocks Perform Better than the Conventional Stocks? A Comparative Study Stocks Listed on the Australian Stock Exchange." Asian Journal of Finance \& Accounting 6 (2): 155. https://doi.org/10.5296/ajfa.v6i2.6072.

Sensoy, Ahmet. 2016. "Systematic Risk in Conventional and Islamic Equity Markets." International Review of Finance 16 (3). Wiley/Blackwell (10.1111): 457-66. https://doi.org/10.1111/irfi.12077.

Setiawan, Budi. 2017. "Perbandingan Kinerja Pasar Modal Syariah Dan Konvensional: Suatu Kajian Empiris Pada Pasar Modal Indonesia." Jurnal Ekonomi Global Masa Kini 8 (1). http://ejournal.uigm.ac.id/index.php/ EGMK/article/view/234/243.

Setiawan, Chandra, and Hesti Oktariza. 2013. "Syariah and Conventional Stocks Performance of Public Companies Listed on Indonesia Stock Exchange." , Journal of Accounting, Finance and Economics 3 (1): 51-64.

Shloma, Elena. 2006. The Financial Performance of Ethical Funds: A Comparative Analysis of the Risk-Adjusted Performance of Ethical and NonEthical Mutual Funds in UK. Sweden: Jönköping International Business School.

Sukmana, Raditya, and Muhamad Kholid. 2012. "Impact of Global Financial Crisis on Islamic and Conventional Stocks in Emerging Market: An Application of ARCH and GARCH Method." Asian Academy of Management Journal of Accounting \& Finance.

Tendelilin, Eduardus. 2001. Analisis Investasi Dan Manajemen Portofolio, Edisi I. Cet. I. Yogyakarta: BPFE.

Touiti, Mariem and Jamel E. Henchiri. 2017. "No Title." In Risk and Performance of Islamic Indexes during Subprime Crisis, , Proceedings of the Second American Academic Research Conference on Global Business, Economics, Finance and Social Sciences. New York-USA: AAR17New York Conference.

Utz, Sabastian, and Maximillian Wimmer. 2014. "Are They Any Good at All? A Financial and Ethical Analysis of Socially Responsible Mutual Funds." Journal of Asset Management 15 (1). Palgrave Macmillan UK: 72-82. 